\title{
Therapeutic and prophylactic measures for winter saprolegniosis in channel catfish
}

\author{
J. E. Bly*, S. M.-A. Quiniou, L. A. Lawson, L. W. Clem \\ Department of Microbiology, The University of Mississippi, Jackson, Mississippi 39216-4505, USA
}

\begin{abstract}
Winter saprolegniosis in channel catfish Ictalurus punctatus is associated with low temperature $\left(\sim 12^{\circ} \mathrm{C}\right)$ induced immunosuppression and invasion by a ubiquitous, opportunistic water mold, identified as a Saprolegnia sp. In this study, attempts were made to identify antimicrobials/chemicals which may (1) be effective for the therapeutic treatment of winter saprolegniosis, and (2) prophylactically control water concentrations of Saprolegnia and hence prevent the onset of disease under laboratory challenge conditions. The antimicrobials used were amphotericin B and the cecropins $A, B$, and P1. While amphotericin B halted Saprolegnia growth, the cecropins were ineffective. The chemicals and herbicides approved for use by the U.S. Food and Drug Adminıstration and considered in this study for the prevention of Saprolegnia zoospore production or cyst germination were used at concentrations less than or equal to those recommended for use in commercial catfish ponds for other purposes. Compared with malachite green (a positive control only), sodium chloride and potassium permanganate were ineffective, while copper sulphate and formalin inhibited both zoospore production and cyst germination. However, at the lowest inhibitory dosage, copper sulphate was toxic to catfish challenged under laboratory conditions; this was likely due to the low alkalinity of our tank water when compared to that of catfish ponds. Several herbicides were tested including diquat, simazine, hydrothol 191, and aquathol K. Only diquat had an inhibitory effect on Saprolegnia growth. In subsequent laboratory challenge experiments, both formalin and diquat were efficacious in preventing the onset of winter saprolegniosis in channel catfish.
\end{abstract}

KEY WORDS: Channel catfish S Saprolegniosis - Temperature Immunity Chemotherapy Antimicrobials

\section{INTRODUCTION}

Winter saprolegniosis (colloquially termed 'winter kill') in channel catfish Ictalurus punctatus has been documented to result from a combination of 2 factors. The first is low-temperature-induced immunosuppression and the second is high water concentrations of Saprolegnia zoospores, i.e. $\geq 5 \mathrm{ml}^{-1}$. Low-temperatureinduced immunosuppression can result from the occurrence of a severe cold weather front; such fronts can lower pond water temperatures by as much as $16^{\circ} \mathrm{C}$ in $24 \mathrm{~h}$ (Bly et al. 1992, 1993). Under laboratory conditions, a temperature decrease of $10^{\circ} \mathrm{C}$ in $24 \mathrm{~h}$ (from 22 to $\sim 12^{\circ} \mathrm{C}$, within the temperature ranges associated with the onset of disease in commercial ponds) induced immunosuppression in catfish for 5 to $8 \mathrm{wk}$, until the fish

•E-mail: bly@fiona.umsmed.edu acclimated to the low temperature (Bly \& Clem 1991, 1992). Saprolegnia undergoes asexual reproduction to release motile zoospores into the water. Although zoospore concentrations are normally $<2 \mathrm{ml}^{-1}$, during the cold winter months, when disease is observed, levels of 5 to $10 \mathrm{ml}^{-1}$ have been recorded (Bly et al. 1992). If catfish are immunosuppressed they do not appear able to inhibit Saprolegnia cyst germination and hyphal penetration of the skin and underlying muscle. However, if catfish are acclimated to $\sim 11^{\circ} \mathrm{C}$, and have regained immunocompetence (Bly \& Clem 1991), they do not become infected (Bly et al. 1992), supporting the contention that an intact immune system protects against this disease. Further corroboration of this hypothesis came from studies wherein catfish held at the immunologically permissive temperature of $22^{\circ} \mathrm{C}$ were injected intramuscularly with viable Saprolegnia hyphae. The hyphae were rapidly destroyed in a classical foreign body response (Bly et al. 1994). Because the 
etiology of this disease is multifactorial, a vaccine would have to be effective in the face of low-temperature-induced immunosuppression or would have to be administered with an immunostimulant which would overcome low-temperature-suppressed immune mechanisms required for protection. As the development of such a vaccine is likely to be a particularly difficult undertaking, a simpler approach would be to therapeutically treat fish exhibiting signs of Saprolegnia associated lesions and/or to prevent the disease vid chemical prophylaxis to limit the concentration of Saprolegnia in commercial production ponds.

In this study attempts were made in the laboratory to inhibit Saprolegnia hyphal growth with antimicrobials and to prevent/reduce zoospore production and/or cyst germination with chemicals and herbicides. Agents showing potential were then tested in laboratory challenge experiments to determine if they could prevent the onset of winter saprolegniosis in catfish. The antimicrobials used were amphotericin B, a clinically potent antifungal agent (Tilton \& McGinnis 1987), and the cecropins $A, B$, and P1, naturally occurring antimicrobials produced in the intestines of insects ( $A$ and $B$; Boman \& Hultmark 1987) and pigs (P1; Boman et al. 1993). Cecropins are potent antibacterial agents and may be inhibitory for Saprolegnia as it has been reported that Achlya and Saprolegnia are sensitive to some antibiotics (Olah \& Farkas 1978, Beakes \& Gay 1980). The chemicals used, sodium chloride, potassium permanganate, copper sulphate, and formalin, are currently approved by the U.S. Food and Drug Administration (FDA) as therapeutics for use in catfish ponds (MacMillan 1985, Schnick 1991). Malachite green which is known to kill fungal growth on catfish eggs was used as a positive control; this chemical is no longer approved for use with food fish due to its teratogenic properties (Alderman 1985, 1994). Herbicides were also used in attempting to inhibit Saprolegnia growth because the Oomycetes are known to have their phylogenetic origins with the chromophyte algae and are members of the Protoctista rather than true fungi (Farkas 1979, Beakes 1989, Dick 1990, KwonChung \& Bennett 1992)

\section{METHODS AND MATERIALS}

Saprolegnia culture. Details concerning the maintenance of Saprolegnia isolates obtained from moribund catfish with overt signs of saprolegniosis have been described previously (Bly et al. 1992). Briefly, 6 Saprolegnia isolates have been maintained on corn meal agar (CMA; Difco, Detroit, MI, USA) at $17^{\circ} \mathrm{C}$ for over $3 \mathrm{yr}$ in this study the CF1 isolate was predominantly used. Isolates were passaged by inverting a block of agar cut from an area of dense hyphal growth onto a new CMA plate. Isolates from the American Type Culture Collection [Saprolegnia sp. (ATCC \#36209), S. diclina (ATCC \#42062), S. ferax (ATCC\#26116), and S. parasitica (ATCC \#22284)] were also used for comparative purposes and cultured as described above.

Zoospore inhibition assays. To produce zoospores, $1 \mathrm{~cm}^{2}$ blocks of agar, covered by Saprolegnia (CF1) hyphal growth, were inverted onto the center of CMA plates and surrounded by autoclaved hemp seeds Once the seeds were completely covered with Saprolegnia hyphae $\left(-5 \mathrm{~d}\right.$ at $\left.22^{\circ} \mathrm{C}\right)$, blocks of agar containing hemp seeds were placed in floating mesh baskets in $1 \mathrm{l}$ plastic containers containing 11 of well water. The containers were suspended in water baths which could be chilled from ambient temperature $\left(-22^{\circ} \mathrm{C}\right)$ to $12 \pm 1^{\circ} \mathrm{C}$ in $24 \mathrm{~h}$. Water samples were taken immediately before and $4 \mathrm{~d}$ after Saprolegnia was added to the water. Five $0.5 \mathrm{ml}$ aliquots of water were plated onto CMA plates and incubated at 24 or $11^{\circ} \mathrm{C}$ and observed daily for hyphal growth. Hyphal colonies were counted, and the mean number $\pm \mathrm{SD}$ of zoospores produced per $1 \mathrm{ml}$ of water was calculated. In chemical inhibition assays, chemicals were added to the containers along with Saprolegnia, and zoospore concentrations on Day 4 were compared with those in control containers (no chemical)

Cyst germination inhibition assays. To produce cysts, $1 \mathrm{~cm}^{2}$ blocks of CMA covered in Saprolegnia (CF1) hyphae were added to Petri dishes containing $30 \mathrm{ml}$ of filtered, sterile pond water and maintained at $\sim 22^{\circ} \mathrm{C}$ for $24 \mathrm{~h}$. During the $24 \mathrm{~h}$, Saprolegnia hyphae produced sporangia and released zoospores which quickly encysted on the bottom of the dishes. Cysts and remaining zoospores were counted using a hemocytometer, and aliquots of water were added to 6 well plates to give final concentrations of 8000 cysts per $5 \mathrm{ml}$ of Leibovitz's L-15 medium (L-15; Gibco, Grand Island, NY, USA). This nutrient rich medium was used to mimic nutrient rich catfish flesh and allow cyst germination and dense hyphal growth. If sterile pond water, rather than L-15, was used as a culture medium, cyst germination resulted in very thin hyphae and a very rapid onset of asexual reproduction. Test chemicals were added as required and the cultures incubated at $11^{\circ} \mathrm{C}$. Cultures were examined both macro- and microscopically daily for the presence of germinated cysts.

Chemicals. Chemicals were purchased from Sigma (St. Louis, MO, USA) and used at concentrations less than or equal to the maximum concentrations recommended for use with catfish (Alderman 1985, MacMillan 1985, Durborow et al. 1991): sodium chloride $\leq 100 \mathrm{mg} \mathrm{l}^{-1}$, potassium permanganate $\leq 10 \mathrm{mg} \mathrm{l}^{-1}$, copper sulphate $\leq 200 \mathrm{mg} \mathrm{l}^{-1}$, formalin ( $37 \%$ formaldehyde solution) $\leq 200 \mathrm{mg} \mathrm{l}^{-1}$, and malachite green $\leq 5 \mathrm{mg} \mathrm{l}^{-1}$. 
Amphotericin B (Fungizone; Bristol Myers Squibb, Princeton, NJ, USA) and cecropins A, B, and P1 (Sigma) were used at stock concentrations of 5 and $500 \mu \mathrm{g}$ $\mathrm{ml}^{-1}$, respectively. Herbicides [diquat (Chevron Chemical Company Agricultural Chemical Division, San Francisco, CA, USA), simazine (Ciba-Ceigy Corporation, Greensboro, NC, USA), hydrothol 191 and aquathol $\mathrm{K}$ (Pennwalt Chemical/Equipment/ Health Products, Philadelphia, PA, USA)/ were donated by the Mississippi Department of Wildlife Fisheries and Parks (Fisheries Bureau, PO Box 451, Jackson, MS 39211, USA). The concentrations used were as follows: diquat, 0.125 to $1 \mathrm{Hl} \mathrm{l}^{-1}$; simazine, 0.2 to $3 \mathrm{mg} \mathrm{l}^{-1}$; hydrothol $191,0.625$ to $1,1 \mathrm{l}^{-1}$; and aquathol $\mathrm{K}, 1.25$ to $10 \mu \mathrm{l} \mathrm{l} \mathrm{l}^{-1}$ These were within the guidelines recommended for use with food fish (Hull et al. 1967, Johnson \& Finley 1980, Durborow \& Tucker 1992).

Inhibition assays with antimicrobial agents. One $\mathrm{cm}^{2}$ blocks of CMA covered with Saprolegnia hyphae were inverted onto new CMA plates. Sterile filter paper disks (Difco) were placed on the agar approximately $2 \mathrm{~cm}$ away from the blocks. The disks were then saturated with $25 \mu \mathrm{l}$ of antimicrobial agent solution, and the cultures incubated at $22^{\circ} \mathrm{C}$ and monitored for inhibition of Saprolegnia hyphal growth around the antimicrobial-agent-containing disks. In positive control experiments, Escherichia coli BB4 was streaked onto thirds of new CMA plates and filter paper disks were placed on the center of the expected growth area. An aliquot ( $25 \mu l)$ of antimicrobial agent solution was then added to each paper disk.

Challenge experiments. Laboratory challenge protocols have been described in detail elsewhere (Bly et al. 1992). Briefly, 8 to 12 juvenile catfish were held in $36 \mathrm{l}$ tanks complete with air stone and filter. Floating mesh baskets were added to challenge tanks containing 5 agar blocks, each with a hemp seed covered with Saprolegnia (CF1) hyphae. The fish tanks were supported in a water jacket which could be chilled from ambient temperature $\left(\sim 22^{\circ} \mathrm{C}\right)$ to $12^{\circ} \mathrm{C}$ in $24 \mathrm{~h}$. Water samples were taken before Saprolegnia was added (Day 0) and on Days 4 and 8 post-challenge to assess zoospore numbers. At the beginning of the challenge, chemicals were added to the water along with the addition of Saprolegnia, immediately before the chiller units were activated. Tank water was maintained at $12 \pm 1^{\circ} \mathrm{C}$ for a total of $21 \mathrm{~d}$, at which time the experiments were terminated. To assess the effects of chemicals, fish were monitored for mortalities and signs of saprolegniosis for $21 \mathrm{~d}$ post-challenge, and compared with controls: positive control = Saprolegnia added and negative control = no Saprolegnia added. Challenge protocols were repeated $\geq 3$ times to ensure valid statistical analyses by $t$-test, in order to compare survival rates at $21 \mathrm{~d}$ in the treated tanks with those in the positive or negative control tanks.

\section{RESULTS}

\section{Antimicrobials}

Amphotericin B and the cecropins A, B, and P1 were tested for their abilities to inhibit the growth of Saprolegnia isolate CF1 hyphae (Fig 1a) Results indicated that although $0.125 \mu \mathrm{g}$ of amphotericin $\mathrm{B}$ was able to
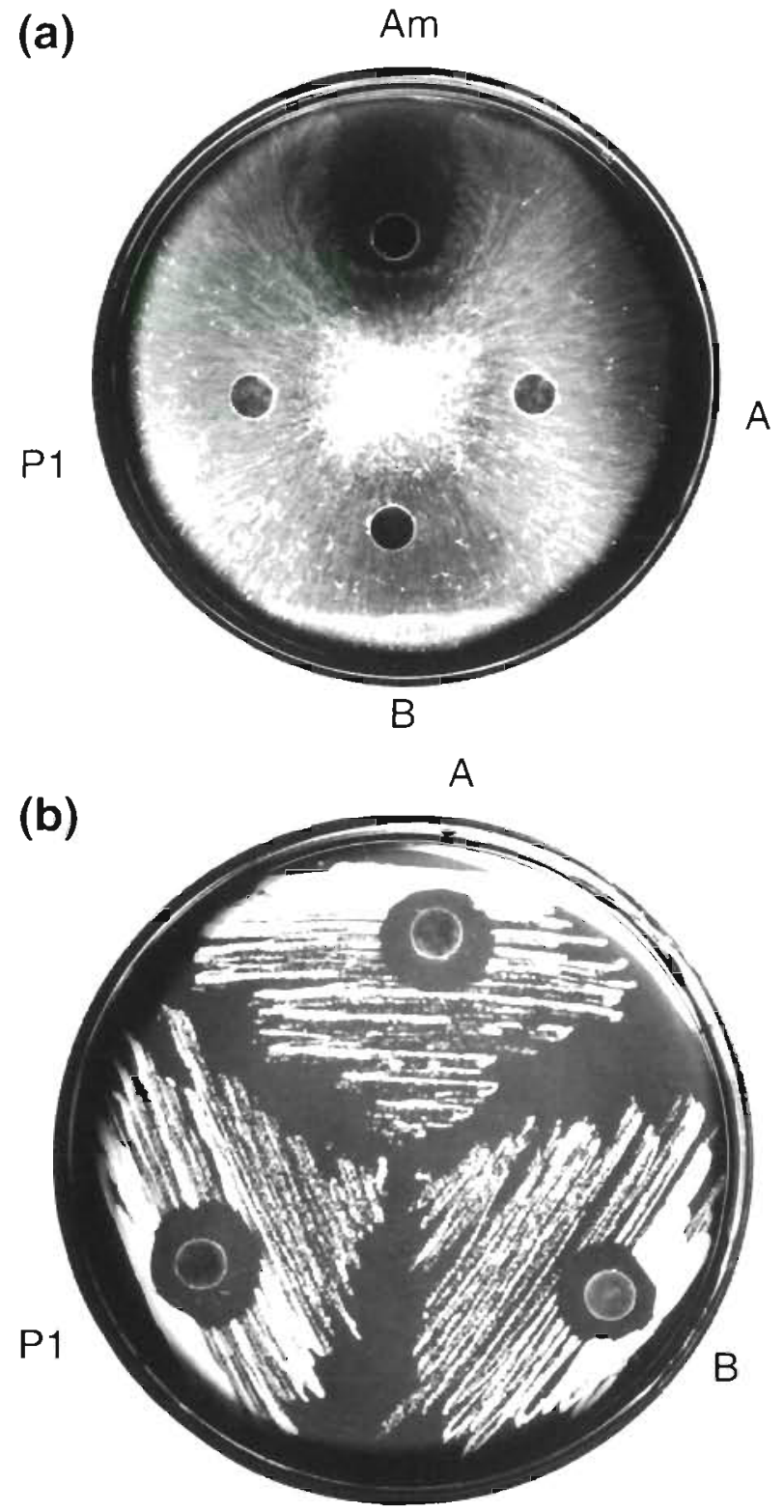

Fig. 1. Inhibition with antimicrobial agents. (a) Inhibitory effects of amphotericin B (Am; $0.125 \mu$ disk $^{-1}$ ) and lack of effects with the cecropins (A, B, and $\mathrm{P} 1 ; 12.5 \mu \mathrm{g}$ disk $^{-1}$ ) on Saprolegnia CF1 hyphal growth. (b) Cecropin control, depicting inhibition of Escherichia coli BB4 growth; all cecropins were used at $12.5 \mu \mathrm{g}$ 
inhibit CF1 growth, none of the cecropins tested had any effect on Saprolegnia growth when used at doses $\leq 12.5 \mu \mathrm{g}$ disk $^{-1}$ In control experiments, all cecropins ( $A, B$, and P1) were effective at inhibiting the growth of Escherichia coli BB4 over the same concentration range; inhibitions of $E$. coli resulting from $12.5 \mu \mathrm{g}$ of each cecropin are shown in Fig. 1 b. Amphotericin B inhibited the growth of all 6 catfish Saprolegnia isolates and ATCC isolates Saprolegnia sp., $S$. diclina, $S$. ferax, and $S$. parasitica (data not shown).

\section{Chemical control of Saprolegnia zoospore production}

Several chemicals were tested for inhibition or suppression of the production of Saprolegnia (CF1) zoospores. Results are given in Table 1 and indicate that if 1 Saprolegnia-covered hemp seed was added to 11 of well water, by Day $4, \geq 300$ zoospores $\mathrm{ml}^{-1}$ water were observed. (Our well water supply contains no Saprolegnia.) Sodium chloride and potassium permanganate were ineffective at reducing zoospore production. Malachite green, the positive control, totally inhibited zoospore production at $2.5 \mathrm{mg} \mathrm{l}^{-1}$ and significantly suppressed zoospore production at concentrations as low as 1.0 to $0.25 \mathrm{mg} \mathrm{l}^{-1}$. Copper sulphate inhibited zoospore production at $2.5 \mathrm{mg} \mathrm{I}^{-1}$ and suppressed production at concentrations $\geq 0.5 \mathrm{mg} \mathrm{l}^{-1}$. Formalin was also inhibitory at $12.5 \mathrm{mg} \mathrm{l}^{-1}$ and was suppressive at $7.5 \mathrm{mg} \mathrm{l}^{-1}$.

\section{Chemical control of cyst germination}

Saprolegnia isolate CF1 zoospores were placed in 6 well plates and allowed to encyst. Various concentrations of chemicals were added and the cultures were incubated at $11^{\circ} \mathrm{C}$. If the chemical had no effect on cyst germination, hyphae rapidly grew and in 4 to $6 \mathrm{~d}$ totally covered the well, whereas if germination was inhibited the well remained clear Fig. 2 shows the results obtained with malachite green (as a positive control) and formalin on the germination of 8000 cysts contained in $5 \mathrm{ml}$ of $\mathrm{L}-15$ medium. All protocols were in duplicate and photographs were taken $6 \mathrm{~d}$ after the cultures at $11^{\circ} \mathrm{C}$ were initiated. There was confluent hyphal growth in the germination control, whereas growth was inhibited by $2.5 \mathrm{mg} \mathrm{l}^{-1}$ malachite green and $250 \mathrm{mg} \mathrm{l}^{-1}$ formalin. At lower doses of either chemical, growth was slowed but cyst germination was not inhibited. Potassium permanganate, copper sulphate, and sodium chloride had no effect on cyst germination at the highest doses approved by the FDA for use with catfish (data not shown). Microscopic analyses (Fig. 3) indicated that malachite green at $2.5 \mathrm{mg} \mathrm{I}^{-1}$ inhibited Saprolegnia germ tube growth; at $1 \mathrm{mg} \mathrm{l}^{-1}$ it slowed the growth of Saprolegnia and rendered many of the hyphae permeable, making them appear black due to uptake of malachite green. Formalin at $250 \mathrm{mg} \mathrm{l}^{-1}$ completely inhibited cyst germination for up to $12 \mathrm{~d}$, a point exceeding the time expected for formaldehyde loss by evaporation.

\section{Control of Saprolegnia growth with herbicides}

Diquat, simazine, hydrothol 191, and aquathol K were tested for their effectiveness in inhibiting Saprolegnia (CF1) zoospore production and/or cyst germination as described above for chemical inhibition. Only diquat was effective. At concentrations of 0.5 and $0.25 \mathrm{ul} \mathrm{l}^{-1}$, diquat significantly suppressed zoospore production $(p<0.0001$ and $p=0.0210$, respectively), but it had no effect at $0.12 \mu \mathrm{l}^{-1}$ (data not shown). Cyst germination was also slowed by diquat $\left(1 \mu \mathrm{l} \mathrm{l}^{-1}\right)$, the treatment resulting in characteristic stunted star-like colonies after incubation at $11^{\circ} \mathrm{C}$ for $6 \mathrm{~d}$ (Fig. 4 ). 


\section{Laboratory challenge experiments}

To determine if copper sulphate, formalin, and/or diquat could be used prophylactically to prevent the onset of winter saprolegniosis in catfish, laboratory challenge experiments were conducted. Results are given in Table 2 for formalin and diquat. In the positive control catfish challenge tanks, Saprolegnia was
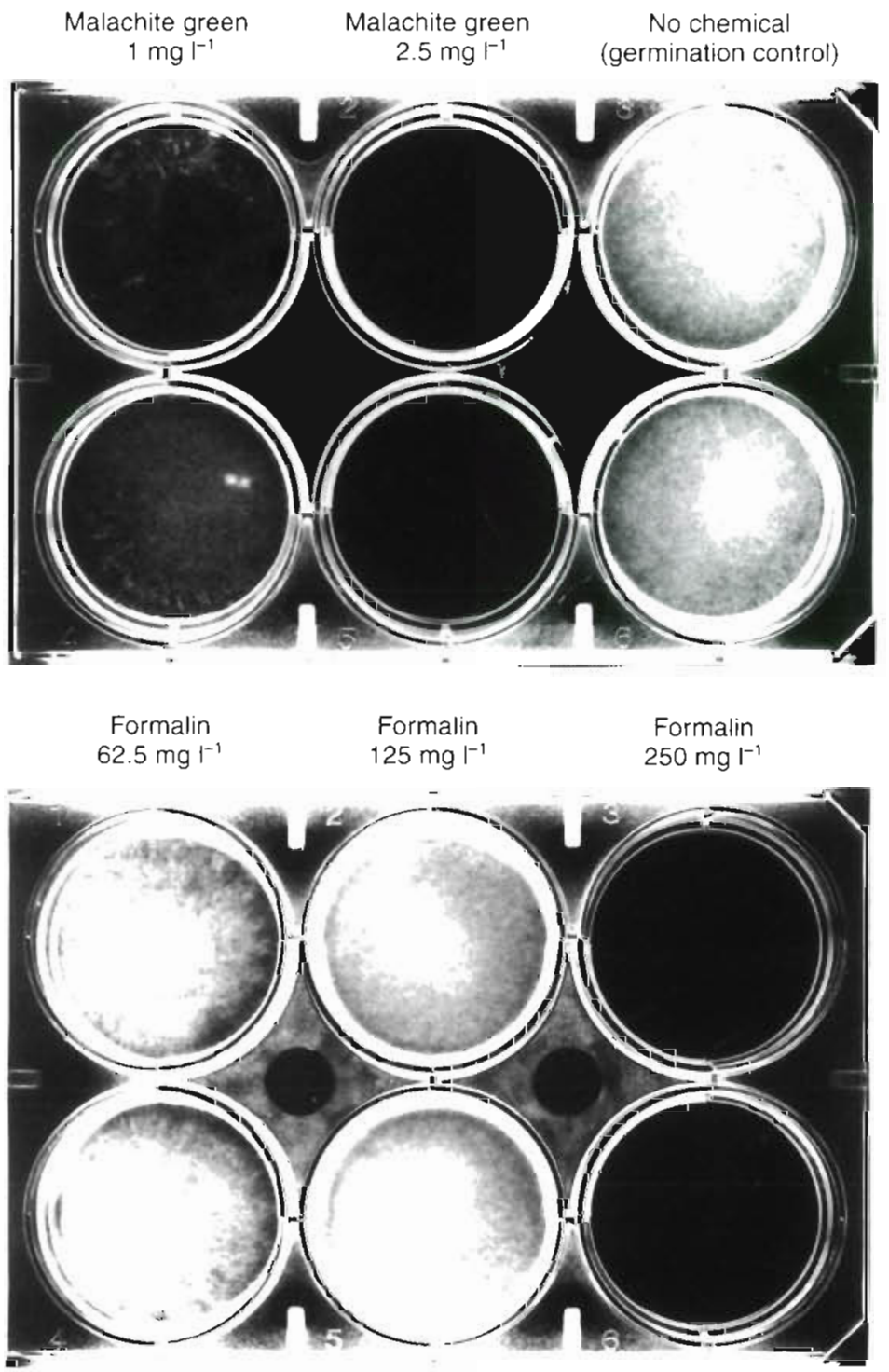

Fig. 2. Inhibition of Saprolegnia (CF1) cyst germination by various chemicals. Upper and lower wells on each plate are replicates. Each well contained 8000 Saprolegnia zoospores in $5 \mathrm{ml}$ of L-15 medium and no chemical (control), or malachite green or formalin at the doses indicated. Confluent hyphal growth occurred in the germination control wells and with formalin at 62.5 and $125 \mathrm{mg} \mathrm{l}^{-1}$; partial inhibition of hyphal growth was observed with malachite green at $1 \mathrm{mg} \mathrm{l}^{-1}$; and what appeared to be total inhibition of cyst germination occurred with $2.5 \mathrm{mg} \mathrm{l}^{-1}$ malachite green and $250 \mathrm{mg} \mathrm{l}^{-1}$ formalin. These cultures had been incubated at $11^{\circ} \mathrm{C}$ for $6 \mathrm{~d}$ added to the water to yield zoospore concentrations of 30 to $40 \mathrm{ml}^{-1}$ on Days 4 and 8 post-challenge. Fish in the positive control tanks exhibited gross Saprolegniaassociated lesions (denoted by ${ }^{*}$ in the table) by Day 4 post-challenge, with a majority of the fish dying by Day 14 . The $21 \mathrm{~d}$ survival rate was $3.4 \%$. In negative control experiments, 2 fish out of 38 died without signs of winter saprolegniosis, giving a $21 \mathrm{~d}$ survival rate of $94.4 \%$. Copper sulphate at $0.5 \mathrm{mg} \mathrm{l}^{-1}$ was toxic to catfish held at $11^{\circ} \mathrm{C}$, with $100 \%$ mortality observed within 7 d (data not shown). Formalin used at $25 \mathrm{mg} \mathrm{l}^{-1}$ gave a survival rate of $96.6 \%$. One fish lout of 29 challenged) died and was observed to have signs of saprolegniosis. At $12.5 \mathrm{mg}$ $1^{-1}$, formalin was less effective at preventing saprolegniosis although the survival rate $(86,7 \%)$ was still significant when compared to the positive controls. In the experiments with formalin at $12.5 \mathrm{mg} \mathrm{l}^{-1}, 6$ fish (out of 45 challenged) died with only 4 exhibiting signs of saprolegniosis. These results suggested that concentrations of formalin lower than $12.5 \mathrm{mg} \mathrm{l}^{-1}$ would be even less effective at preventing disease and so lower concentrations of formalin were not tested. At a higher concentration of formalin $\left(50 \mathrm{mg} \mathrm{l}^{-1}\right)$ all fish died in the first week post-challenge with no signs of saprolegniosis (data not shown), suggesting formalin toxicity. Diquat at $\geq 0.5 \mu l l^{-1}$ was toxic to all catfish in the challenge experiments, i.e. $100 \%$ mortality within $7 \mathrm{~d}$ (data not shown). At $0.25 \mu \mathrm{ll}^{-1}$. diquat toxicity was less, and although the survival rate after $21 \mathrm{~d}$ was only $56.2 \%$, it was still significantly higher than the $3.4 \%$ seen in the positive challenge controls. At a diquat concentration of $0.125 \mathrm{\mu l} \mathrm{l}^{-1}$, the mortality rate was only $10.7 \%$ and was not significantly different from that of the negative control, i.e. $5.6 \%$. However, because the 3 deaths recorded using $0.125 \mathrm{\mu l} \mathrm{l}^{-1}$ were not associated with saprolegniosis, diquat may still be toxic at this level. In summary, formalin at $25 \mathrm{mg} \mathrm{l}^{-1}$ and diquat at $0.125 \mathrm{\mu l} \mathrm{l}^{-1}$ were effective at preventing winter saprolegniosis in catfish challenged under laboratory conditions.

\section{DISCUSSION}

Although the exact pathogenesis of saprolegniosis is unclear, based on information from laboratory challenge experiments (Bly 


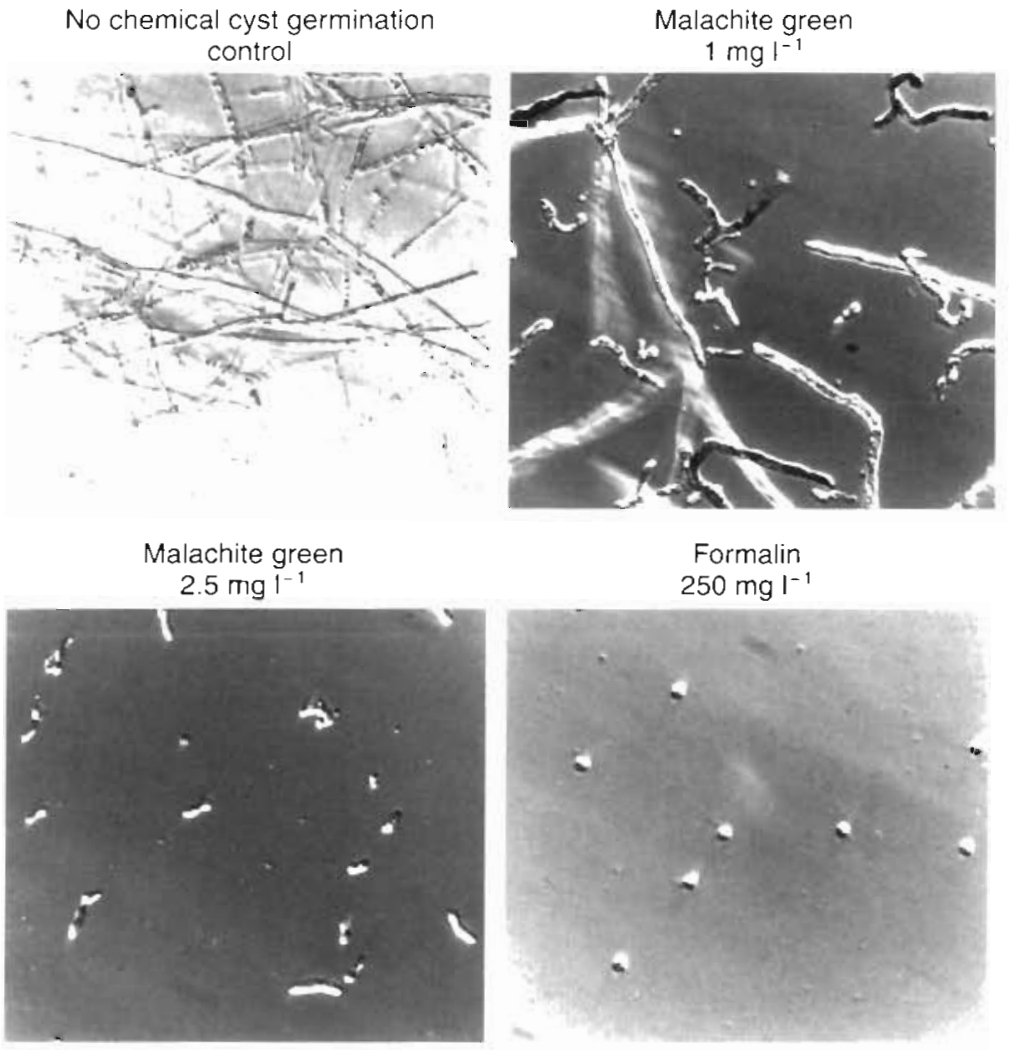

Fig. 3. Microscopic analyses of Saprolegnia cyst germination (200x). The control (no chemical), chemicals, and doses added are indicated. Cultures were maintained at $11^{\circ} \mathrm{C}$ for $6 \mathrm{~d}$. Compared with the germination control, malachite green inhibited cyst germination at the germ tube stage $\left(2.5 \mathrm{mg} \mathrm{1}^{-1}\right)$ or slowed hyphal growth and rendered some of the hyphae permeable, thus allowing the entry of malachite green (appearance of black hyphae $1 \mathrm{mg} \mathrm{I}^{-1}$ ). Formalin at $250 \mathrm{mg} \mathrm{l}^{-1}$ totally inhibited cyst germination

et al, 1992) and field studies (Bly et al. 1993), the following scenario is proposed. Saprolegnia zoospores become embedded in catfish mucus, encyst, and are sloughed as the mucus is replaced. This process is documented in trout (Wood et al. 1988). Potentially, if mucus secretion is slowed for a short period, say 2 to $4 \mathrm{~d}$, cysts trapped in the mucus would have time to germinate. In order to induce winter saprolegniosis, a rapid decrease in environmental temperature is required. Although it is documented that a rapid decrease in water temperature leaves catfish immunosuppressed (Bly \& Clem 1991, 1992), it is also possible that the 'temperature drop' impairs the function of mucus-secreting goblet cells, a notion which has recently been confirmed in our laboratory (unpubl. data). Once Saprolegnia germ tubes penetrate fish skin, it is theorized that hyphal growth meets with little immunological resistance in immunosuppressed fish, thus allowing the development of gross hyphaeassociated skin lesions within a week following a rapid drop in temperature.

Saprolegniosis may thus be prevented by inhibiting sporangia development and the release of zoospores into pond water and/or by inhibiting cyst germination. Furthermore, the disease may be therapeutically treated by agents which can inhibit Saprolegnia hyphal growth within lesions. The simplest or most direct treatment would be to add an antimicrobial agent directly into the pond water or to incorporate it into catfish feed. The present study indicates that amphotericin B is an effective antimicrobial agent even though $S_{a-}$ prolegnia is not a fungus. Amphotericin B binds ergosterol in fungal cell membranes, causing a rapid leakage of potassium which inhibits a variety of meta-

Table 2. Effects of formalin or diquat on winter saprolegniosis in channel catfish Ictalurus punctatus as determined by laboratory challengle experiments. $\mathrm{D}$ : days post-challenge; $\mathrm{p}$ : $\mathrm{p}$-value, comparing experimental \% survival with that of the positive control on D21

\begin{tabular}{|c|c|c|c|c|c|c|c|c|c|}
\hline \multirow{2}{*}{ Treatment } & \multicolumn{4}{|c|}{ No. of fish dead on: } & \multicolumn{3}{|c|}{ D21, cumulative no. } & \multirow{2}{*}{$\%$ survival } & \multirow{2}{*}{$\mathrm{p}$} \\
\hline & $D 4$ & D8 & D 14 & D21 & Dead & Alive & Total & & \\
\hline Positive control. ${ }^{a}$ & $33^{\circ}$ & $22^{\bullet}$ & $1 \cdot$ & $1^{\cdot}$ & 57 & 2 & 59 & 3.4 & \\
\hline Negative control ${ }^{\mathrm{b}}$ & 0 & 2 & 0 & 0 & 2 & 34 & 36 & 94.4 & $<0.0001$ \\
\hline Formalin $25 \mathrm{mg} \mathrm{I}^{-1}$ & 0 & 1. & 0 & 0 & 1 & 28 & 29 & 96.6 & $<0.0001$ \\
\hline Formalin $12.5 \mathrm{mg} \mathrm{l}^{-1}$ & 2 & 0 & 2 & $2 \cdot$ & 6 & 39 & 45 & 86.7 & $<0.0002$ \\
\hline Diquat $0.25 \mu \mathrm{l}^{-1}$ & 1 & 6 & 6 & 1 & 14 & 18 & 32 & 56.2 & $<0.0004$ \\
\hline Diquat $0.125 \mu \mathrm{l}^{-1}$ & 2 & 0 & 1 & 0 & 3 & 25 & 28 & 89.3 & $<0.0019$ \\
\hline
\end{tabular}


No chemical cyst germination control

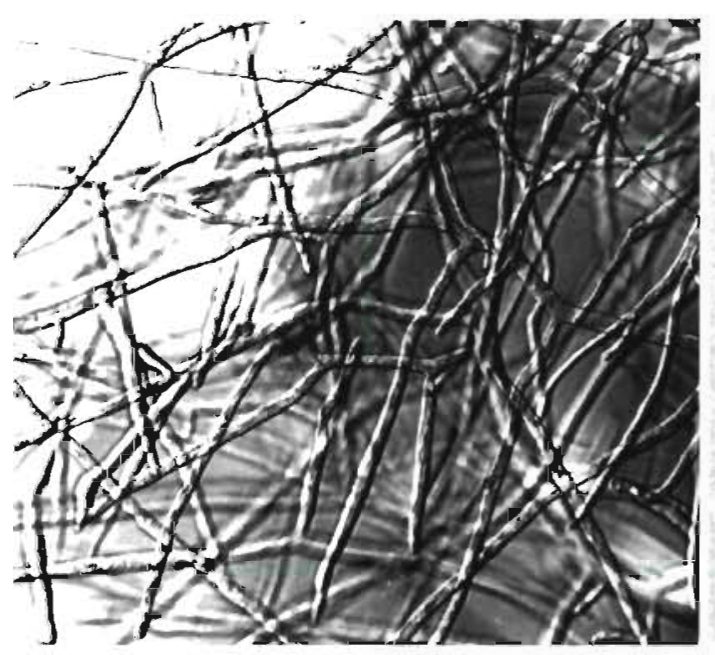

Diquat $\left(\left.1 \mu\right|^{-1}\right)$

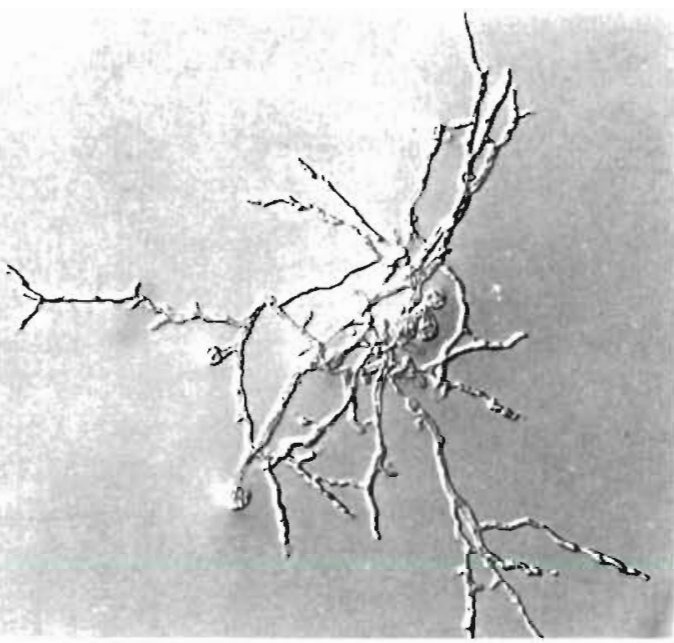

Fig. 4. Microscopic analyses of diquat suppression of Saprolegnia (CF1) growth from cysts (200x). Diquat at $1 \mu 11^{-1}$ suppressed the growth of hyphae once cysts had germinated to give a stunted star-shaped colony composed of apparently damaged (i.e. thin, misshapen, and granular) hyphae

bolic processes (Tilton \& McGinnis 1987); the Saprolegnia also have sterols in the cell membrane (Berg et al. 1983). Although the use of amphotericin $B$ with catfish is not foreseen, agents with similar actions should be investigated for their potential in the treatment of this disease.

The cecropins are potential candidates for the production of transgenic catfish, as they are natural antimicrobials secreted into the intestines of insects and pigs (Boman \& Hultmark 1987, Boman et al. 1993). Several isolates of Saprolegnia and Achlya have been noted to be sensitive to certain antibiotics (Olah \& Farkas 1978, Beakes \& Gay 1980). However, results from the present study indicate that Saprolegnia is not affected by cecropins and hence transgenic catfish able to produce cecropins would probably not be able to combat Saprolegnia infections.

Malachite green was used in the present study as an effective positive control, preventing Saprolegnia zoospore production and cyst germination. However, it has been withdrawn by the FDA for use with food fish due to its teratogenic properties (Alderman 1985, 1994, Stoskopf 1993). Sodium chloride has been indicated for treatment of fungi (Stoskopf 1993) but was ineffective at preventing Saprolegnia growth in this study. Potassium permanganate and copper sulphate are successfully used in the catfish industry to control external parasites (MacMillan 1985), and copper sulphate is also an effective herbicide (Durborow \& Tucker 1992). In this study potassium permanganate was ineffective at preventing Saprolegnia growth, corroborating a recent finding by Marking et al. (1994) with S. hypogyna. These observations are of interest because potassium permanganate is used to control fungal infections on trout eggs (Marking et al. 1994). Copper sulphate inhibited Saprolegnia growth, but unfortunately was toxic to catfish when used in laboratory challenge experiments. Toxicity was likely due to the well water used in our challenge experiments, which has low hardness and alkalinity, i.e. both are 20 to $40 \mathrm{mg} \mathrm{l}^{-1}$ and thus favor copper sulphate toxicity (Schwedler et al. 1985). To use copper sulphate at $0.5,1.0$, or $2.5 \mathrm{mg}^{-1}$ in commercial catfish ponds, alkalinity would have to be 50,100 , or 250 ppm, respectively; these values fall within the desired ranges for hardness and alkalinity for catfish culture, i.e. between 20 and $300 \mathrm{mg} \mathrm{l}^{-1}$ (Wellborn 1986). Formalin, which is used as an antifungal agent in catfish hatcheries, inhibited Saprolegnia growth and was quite effective at preventing saprolegniosis in laboratory challenge experiments at both 12.5 and $25 \mathrm{mg}$ $\mathrm{l}^{-1}$. However, at $50 \mathrm{mg} \mathrm{l}^{-1}$ formalin was toxic for catfish. Although the action of formalin on Saprolegnia is unknown, formaldehyde is a strong alkylating agent which can be used as a bactericidal agent at high concentrations but is only bacteriostatic at lower concentrations. Because formaldehyde is a gas, the activity is soon lost from water but in these studies the action on cyst germination was permanent and was sufficiently stable to prevent the onset of disease in challenge experiments. As both copper sulphate and formalin at the doses used in these challenge experiments are already FDA-approved for use in catfish ponds, they must obviously be considered as affordable methods of treatment. However, a pond cannot be screened for Saprolegnia zoospore levels if water temperatures are 
warm, i.e. $\geq 17^{\circ} \mathrm{C}$, because under such conditions Saprolegnia is outcompeted by other microorganisms (Bly et al. 1993). At lower temperatures, sampling for Saprolegnia takes $\sim 4$ d to yield results, thus ponds that pose a threat of saprolegniosis cannot be rapidly identified. Depending on cost effectiveness, it may still be worthwhile to treat ponds which have a history of saprolegniosis (indicating the potential for high levels of Saprolegnia) immediately after passage of a severe cold weather front that results in an acute decrease in pond water temperature.

Concerning the herbicides used, only diquat suppressed Saprolegnia growth. Diquat is approved for use in catfish ponds to control algae as well as submerged and emergent weeds. At low concentrations, $0.125 \mathrm{\mu l} \mathrm{l}^{-1}$, diquat was effective at preventing saprolegniosis in laboratory challenge experiments. At higher concentrations, toxicity was a problem. However, it must again be noted that the quality of well water used in our laboratory challenge experiments was quite different from that in catfish ponds, and may have favored diquat toxicity. Unfortunately, specific information concerning diquat toxicity for catfish is apparently not available. However, diquat toxicity for other species varied considerably, e.g. the $96 \mathrm{~h} \mathrm{LC}_{50}$ for rainbow trout was $10 \mathrm{mg} \mathrm{l}^{-1}$ and for bluegill was $245 \mathrm{mg} \mathrm{l}^{-1}$ (Morgan \& Brunson 1989). It is also known that diquat toxicity decreases with increasing water hardness (Johnson \& Finley 1980). Furthermore, diquat is inactivated by clay particles in pond water (Durborow \& Tucker 1992), thus while more diquat may be required in a catfish pond to give results similar to those seen in the laboratory, it may be less toxic due to increased water hardness. Another study which used herbicides, including diquat, to inhibit Saprolegnia growth (Schreck et al. 1990) noted that diquat was the only herbicide effective against Saprolegniainfected rainbow trout eggs.

In summary, these studies indicate the potential for the treatment and/or prevention of winter saprolegniosis in channel catfish.

Acknowledgements. We thank Mr T Holman and Mr W. F. Nazary for supplying herbicides and pertinent information used in this study, Mr L. Thompson and Mr B. Dunlap for supplying juvenile catfish, Dr D. Bernanke for use of his inverted microscope and camera, and Mr W. Devere for photography. This study was supported in part by NIH Grant 1-R37-Al19530 and USDA NRI Competitive Grant 94-37204-0447.

\section{LITERATURE CITED}

Alderman DJ (1985) Malachite green: a review. J Fish Dis 8: $289-298$

Alderman DJ (1994) Control of Oomycete pathogens in aquaculture. In: Mueller GJ (ed) Salmon saprolegniasis. DOE/BP-02836-1 US Dept Energy, Portland, p 111-129
Beakes GW (1989) Oomycete fungi: their phylogeny and relationship to chromophyte algae. In: Green JC, Leadbeater BSC, Diver WL (eds) The chromophyte algae: problems and perspectives. Systematics Association Special Volume No. 38. Clarendon Press, Oxford, p 324-342

Beakes GW, Gay JL (1980) Effects of streptomycin on the growth and sporulation of Saprolegnia spp. J Gen Microbiol 19:361-371

Berg LR, Patterson GW, Lusby WR (1983) Effects of triarimol and tridemorph on sterol biosynthesis in Saprolegnia ferax. Lipids 18:448-452

Bly JE, Clem LW (1991) Temperature-mediated processes in teleost immunity: in vitro immunosuppression induced by in vivo low temperature in channel catfish. Vet Immunol Immunopathol 28:365-377

Bly JE, Clem LW (1992) Temperature and teleost immune functions. Fish Shellfish Immunol 2:159-171

Bly JE, Lawson LA, Abdel-Aziz ES, Clem LW (1994) Channel catfish, Ictalurus punctatus, immunity to Saprolegnia sp. $J$ appl Aquacult 3:35-50

Bly JE, Lawson LA, Dale DJ, Szalai AJ, Durborow RM, Clem LW (1992) Winter saprolegniosis in channel catfish. Dis aquat Org 13:155-164

Bly JE, Lawson LA, Szalai AJ, Clem LW (1993) Environmental factors affecting outbreaks of winter saprolegniosis in channel catfish (Ictalurus punctatus). J Fish Dis 16: $541-549$

Boman HG, Agerberth B, Boman A (1993) Mechanisms of action on Escherichia coli of cecropin P1 and PR-39, two antibacterial peptides from pig intestine. Infect Immunol 61:2978-2984

Boman HG, Hultmark D (1987) Cell-free immunity in insects. A Rev Microbiol 41:103-26

Dick MW (1990) Phylum Oomycota. In: Margulis L, Corliss JO, Melkonias M, Chapman DJ, McKhann HI (eds) Handbook of Protoctista. Jones and Bartlett Publishers, Boston, p 661-685

Durborow RM, Taylor PW, Crosby MD, Santucci TD (1991) Fish mortality in the Mississippi catfish farming industry in 1988: causes and treatments. J Wildl Dis 27:144-147

Durborow RM, Tucker CS (1992) Aquatic weed control in catfish ponds. Kentucky State University Cooperative Extension and USDI Fish and Wildlife Service, Starkville

Farkas V (1979) Biosynthesis of cell walls of fungi. Microbiol Rev 43:117-144

Hull $H$, Barrier G, Frans R, Hilton J, Knake E, Moreland D, Zick W (1967) Herbicide handbook of the weed soclety of America. WF Humphreys Press, Geneva, NY

Johnson WW, Finley MT (1980) Handbook of acute toxicity of chemicals to fish and aquatic invertebrates. USDI Fish and Wildlife Service Resource Publication 137. Ft. Collins

Kwon-Chung KJ, Bennett JE (1992) Medical mycology. Lea and Febiger, Malvern, PA, p 5

MacMillan JR (1985) Infectious diseases. In: Tucker CS (ed) Channel catfish culture. Elsevier Science Publishers, Amsterdam, p 405-496

Marking LL, Rach JJ, Schreier TM (1994) Search for antifungal agents in fish culture. In: Mueller GJ (ed) Salmon saprolegniasis. DOE/BP-02836-1 US Dept Energy, Portland, p 131-148

Morgan ER, Brunson M (1989) Agricultural chemical toxicity to select aquatic animals: bluegill, channel catfish, rainbow trout, crawfish, and freshwater shrimp. Mississippi State University Cooperative Extension Service and US Department of Agriculture Publication no. 1455. Starkville

Olah J, Farkas J (1978) Effect of temperature, pH, antibiotics, 
formalin and malachite green on the growth and survival of Saprolegnia and Achlya parasitic on fish. Aquaculture 13:273-288

Schnick RA (1991) Therapeutic compounds. Annual Agricultural Outlook Conference. Outlook '92. L's Dept of Agriculture, Washington, DC, p 61-72

Schreck C, Fitzpatrick M, Marking LL, Rach JJ, Jeffrey SM (1990) Research to identify effective antifungal agents. Annual Report 1990. USDOE serial no. 27957962. Bonneville Power Administration, Portland, OR

Schwedler TE, Tucker CS, Beleau MH (1985) Non-infectious diseases. In: Tucker CS (ed) Channel catfish culture. Elsevier Science Publıshers, Amsterdam, p 497-542

Responsible Subject Editor: T Evelyn, Nanaimo, British Columbia, Canada
Stoskopf MK (1993) Fish medicine. WB Saunders Company, Harcourt Brace Jovanovich, Philadelphia, p 832-839

Tilton RC, McGinnis MR (1987) Fundamentals of mycology. In Howard BJ, Klass J, Rubin SJ, Weissfeld AS, Tilton RC (eds) Clinical and pathogenic microbiology. The CV Mosby Company, St Louis, p 515-533

Wellborn TL (1986) Catfish farmer's handbook. Mississippi State University Cooperative Extensıon Service Publication 1549, Starkville, p 35

Wood SE, Willoughby LG, Beakes GW (1988) Experimental studies on uptake and interaction of spores of the Saprolegnia diclina-parasitica complex with external mucus of brown trout (Salmo trutta). Trans Br Mycol Soc 90:63-73

Manuscript first received: February 28, 1995

Revised version accepted: August 22, 1995 